\section{Acute myelomonocytic leukaemia and multiple myeloma after sulphinpyrazone and colchicine treatment of gout}

Mild haematological toxicity was noted during a five-month study in which 22 patients with gout received the uricosuric drug sulphinpyrazone (table 1). Eight developed a moderate granulocytopenia compared with only four out of 22 age- and sex-matched controls with rheumatoid arthritis. This difference was not, however, statistically significant $(P=0 \cdot 3)$. In a long-term study fatal blood dycrasias occurred in three out of 25 patients with gout who took sulphinpyrazone for $2 \cdot 8$ to 14 years and colchicine intermittently for shorter intervals.

\section{Case reports}

Case 1-A 69-year-old house painter with a nine-year history of gou received sulphinpyrazone regularly and colchicine intermittently during the four years before his death from acute myelomonocytic leukaemia in 1962 No exposure to solvents was recorded. The terminal illness was characterised by considerable anaemia, thrombocytopenia, a preponderence of immature lymphocytes with monocytoid features in the peripheral blood, and hepatic and splenic leukaemic infiltrates at necropsy.

Case 2-A 72-year-old merchant who had had gout for 16 years received continuous treatment with sulphinpyrazone for 14 years before his death from acute myelomonocytic leukaemia in 1972. Colchicine had not been used within the last 10 years. He received trifluoperazine, chlordiazepoxide, and gluthethamide for acute alcoholism and depression in 1961 and 1962 ; reserpine for hypertension in 1963; nylidrin for intermittent claudication in 1967; and propranolol and glyceryl trinitrate for angina pectoris in 1972 . The terminal diagnosis was confirmed by the same findings as in case 1

Case 3-A 79-year-old accountant who had had gout for 13 years received nearly continuous sulphinpyrazone for eight years and colchicine for one year. After five years a transient leucopenia and thrombocytopenia briefly interrupted this treatment, which was finally discontinued three years before his death from multiple myeloma in 1971. This diagnosis was confirmed by a serum monoclonal $\gamma$-globulin spike on electrophoresis, urinary Bence Jones protein, and sheets of plasma cells in the bone marrow.

Another 10 of the 25 patients died (average age $65 \cdot 1$ years). None of them or the remaining survivors developed a haematoproliferative disorder. Platelet and white blood cell counts, however, dropped in several but returned to normal after sulphinpyrazone had been discontinued (see table)

\section{Discussion}

The following evidence may be cited to link sulphinpyrazone and possibly colchicine with the development of these blood dycrasias. Firstly, sulphinpyrazone is chemically related to phenylbutazone and oxyphenylbutazone, drugs that have been implicated in the development of acute leukaemia, ${ }^{1}$ aplastic anaemia, agranulocytosis, and thrombocytopenia. ${ }^{2}$ Secondly, like known leukaemogenic drugs, sulphinpyrazone appears to set the stage for this development by initially causing marrow depression. The lowered platelet and granulocyte values in the peripheral blood of our patients is indirect evidence of such an effect. Thirdly, colchicine may act synergistically with sulphinpyrazone. Colchicine blocks mitosis and has been associated in rare cases with haematological complications and leuk- aemia. ${ }^{3}$ Lastly, some patients with myeloma progress to an acute myelomonocytic leukaemia and other possibly drug-related haemopoietic disorders. ${ }^{4}$ Experimental animals may develop either myeloma or myelomonocytic leukaemia after intraperitoneal injections of mineral oil..$^{5}$ Thus, the occurrence of multiple myeloma in one of our patients might be accepted along with leukaemia as a manifestation of drug toxicity.

Until additional reports of drug toxicity become available, patients with gout receiving sulphinpyrazone and colchicine should undergo careful haematological evaluation. Similar precautions should apply to patients with arterial thrombotic disease being treated with sulphinpyrazone for its additional action in inhibiting platelet aggregation.

This study was supported by grants from USPHS, AM 05069, the Arthritis Foundation for a Clinical Research Centre, and Geigy Pharmaceuticals.

Requests for reprints should be addressed to Dr F R Schmid, Department of Medicine, Northwestern University Medical Centre, 303 E Chicago Avenue, Chicago, Illinois 60611, USA.

${ }^{1}$ Dougan, L, and Woodliff, H J, Medical fournal of Australia, 1962, 1, 217. ${ }^{2}$ Mauer, E F, New England fournal of Medicine, 1955, 253, 404.

${ }^{3}$ Saarni, M I, and Linman, J W, American fournal of Medicine, 1973, 55, 38.

${ }^{4}$ Rosner, F, and Grunwald, H, American fournal of Medicine, 1974, 57, 927.

${ }^{5}$ Metcalf, D, Moore, M A S, and Warner, N L, fournal of the National Cancer Institute, 1969, 43, 983 .

Arthritis-Connective Tissue Diseases Section, Department of Medicine, Northwestern University Medical Centre, Chicago, Illinois 60611, USA

MICHAEL W WITWER, MD, resident (now clinical instructor, departments of medicine and ambulatory and community medicine, University of California, San Francisco)

FRANK R SCHMID, MD, professor and chief

JOSEPH T TESAR, MD, assistant professor

\section{Intraosseous phlebography and fat embolism}

In 1973 we reported two cases of fat embolism after intraosseous phlebography by the pertrochanteric route. One of these patients survived $^{1}$ and one died. ${ }^{2}$ The investigation reported here was undertaken to determine whether or not globules of free fat regularly appear in the blood stream after pertrochanteric phlebography.

\section{Method and results}

Eighteen patients undergoing pertrochanteric phlebography were studied The technique of phlebography was that described by Lea Thomas and Fletcher. ${ }^{3}$ In this method $40-50 \mathrm{ml}$ of water-soluble contrast material is mechanically injected into the marrow cavity of the femur at a pressure of $2 \cdot 8 \mathrm{~kg} / \mathrm{cm}^{2}\left(40 \mathrm{lb} / \mathrm{in}^{2}\right)$. The method was identical to that used in the patients

Haematological toxicity in patients receiving sulphinpyrazone and colchicine

\begin{tabular}{|c|c|c|c|c|c|c|c|c|}
\hline \multirow{3}{*}{$\begin{array}{l}\text { No of } \\
\text { patients }\end{array}$} & \multirow{3}{*}{ Diagnosis } & \multicolumn{2}{|c|}{ Sulphinpyrazone treatment } & \multicolumn{3}{|c|}{ Colchicine treatment } & \multicolumn{2}{|c|}{ Patients with blood toxicity } \\
\hline & & \multirow{2}{*}{$\begin{array}{c}\text { Dose } \\
\text { (mg/day) }\end{array}$} & \multirow{2}{*}{$\begin{array}{c}\text { Mean duration } \\
\text { (yrs) }\end{array}$} & \multirow{2}{*}{$\begin{array}{c}\text { Dose } \\
\text { (mg/day) }\end{array}$} & \multicolumn{2}{|c|}{ No of patients and length of treatment } & \multirow{2}{*}{ 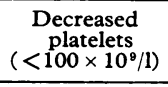 } & \multirow{2}{*}{$\begin{array}{c}\text { Decreased } \\
\text { white cells } \\
\left(<5 \times 10^{9} / 1\right) \\
\end{array}$} \\
\hline & & & & & $<3 \mathrm{yrs}$ & $>3 \mathrm{yrs}$ & & \\
\hline \multicolumn{9}{|c|}{ Long-term administration } \\
\hline 3 & $\begin{array}{c}\text { Gout;* leukaemia } \\
\text { myeloma }\end{array}$ & $\begin{array}{l}300-400 \text { (range: } \\
200-600 \text { ) }\end{array}$ & $\begin{array}{l}8 \cdot 3 \text { (range: } \\
4-14 \text { ) }\end{array}$ & $0 \cdot 6-1 \cdot 2$ & 1 & 2 & 1 & 1 \\
\hline 22 & Gout* & $\begin{array}{c}300-400 \text { (range: } \\
200-600)\end{array}$ & $\begin{array}{r}7 \cdot 0 \text { (range: } \\
2 \cdot 8-13 \cdot 5)\end{array}$ & $0 \cdot 6-1 \cdot 2$ & 14 & 8 & 2 & 3 \\
\hline \multicolumn{9}{|c|}{ Short-term administration } \\
\hline $\begin{array}{l}22 \\
22\end{array}$ & $\begin{array}{c}\text { Gout* } \\
\text { Rheumatoid } \\
\text { arthritis }\end{array}$ & $\begin{array}{c}200 \\
\text { Nonet }\end{array}$ & $\begin{array}{l}0.4 \\
0 \cdot 4\end{array}$ & $\begin{array}{c}0 \cdot 6-1 \cdot 2 \\
0\end{array}$ & $\begin{array}{l}1 \\
0\end{array}$ & & $\begin{array}{l}0+ \\
0 \neq \\
0 \neq\end{array}$ & $11 \S$ \\
\hline
\end{tabular}

*Diagnosis of gout was established by serum urate values greater than $0.48 \mathrm{mmol} / 1(8.0 \mathrm{mg} / 100 \mathrm{ml})$, episodes of acute monoarthritis or oligoarthritis that responded to colchicine, and absence of other arthritic disease. No patient had a myeloproliferative disease or a history of drug ingestion or a metabolic state known to raise serum urate levels. + Patients received either acetylsalicylic acid or ibuprofen.

+ Qualitative examination of peripheral blood film only; quantitative counts not done.

$\$$ Three of the eleven patients had pretreatment counts below $5 \times 10^{9} / 1\left(5000 / \mathrm{mm}^{3}\right)$. 
who had sustained fat embolism. For the purposes of the present investigation three blood samples were taken from an arm vein in each patient; the first after the induction of anaesthesia but before insertion of the pertrochanteric needle; the second five minutes after the first injection of contrast material; and the third 20 minutes later. The blood was allowed to clot and the plasma then examined for the presence of fat globules by the method of Gurd. ${ }^{4}$ This method relies on the separation of the fat globules from plasma by its passage through an $8-\mu \mathrm{m}$ pore size micropore filter. Any fat globules from the plasma are trapped on the filter and can be seen under the microscope after staining with Sudan IV. The triglyceride levels are also measured in the filtrate and compared with those measured in the plasma before filtration. A fall in the triglyceride level confirms that fat has been filtered out. This method was validated by examining blood from two patients with known fat embolism and by examining blood to which fat had been added.

No evidence of circulating fat globules was detected in the blood of 17 of the 18 patients studied. A few fat globules were found in the two postinjection samples from one patient, but there was no significant difference in the plasma triglyceride levels before and after filtration. All 18 patients remained well after phlebography and none showed any symptoms of a fat embolism syndrome. Multiple fat globules were seen on the filter after passage of plasma from the two patients examined who were known to be suffering from traumatic fat embolism.

\section{Conclusion}

Although one of the 18 patients undergoing phlebography showed evidence of a few circulating fat globules, subclinical fat embolism is not common after pertrochanteric phlebography. About 200 pertrochanteric phlebograms have been performed at St Thomas's Hospital during the last six years and only one episode of clinically apparent fat embolism has occurred. We believe therefore that while the clinician and the radiologist should be aware of the possibility of its occurrence in patients undergoing intraosseous phlebography, it is not a contraindication to this valuable technique, for which there is sometimes no alternative.

We acknowledge the help of the staff of the department of chemical pathology, St Thomas's Hospital, who performed the plasma triglyceride estimations.

${ }^{1}$ Young, A E, et al, British Medical fournal, 1973, 4, 592.

2 Lea Thomas, M, and Tighe, J R, Lancet, 1973, 2, 1415.

${ }^{3}$ Lea Thomas, M, and Fletcher, E W L, Clinical Radiology, 1967, 18, 369.

${ }^{4}$ Gurd, A R, Fournal of Bone and foint Surgery, 1970, 52B, 732.

\section{St Thomas's Hospital, London SE1 7EH}

A E YOUNG, MA, FRCs, lecturer in surgery

$M$ LEA THOMAS, FRCP, FRCR, consultant radiologist

$\mathrm{N}$ L BROWSE, MD, FRCS, professor of vascular surgery

\section{Therapeutic value of a supporting brassière in mastodynia}

Pain in the breast is common, and there are relatively few women who do not experience premenstrual discomfort and tenderness at some time during reproductive life. Most of those who seek medical advice are satisfied with reassurance that they do not have cancer of the breast, but about $6 \%$ experience severe and persistent pain that requires some form of treatment in addition to reassurance. The cause of mastodynia is seldom fully understood. In many patients clinical features of fibroadenosis or duct ectasia are present but in others the symptoms seem to arise from the mechanical effect of heavy, pendulous breasts. Whatever the cause, most authorities agree that adequate support for the breasts is an important part of treatment. ${ }^{12}$ Strapping with adhesive plaster has been suggested ${ }^{3}$ but is not practical as a long-term measure and most surgeons recommend a firm supporting brassière. For various reasons this advice is often disregarded and even when it is followed the brassière selected may be inappropriate for the patient's needs.

\section{Methods and results}

Between 1 March 1974 and 31 December 1975114 patients were individually fitted with a special brassière as the sole means of treatment. Treatment was considered necessary when two of the following questions were answered in the affirmative: (1) Does the pain last for more than seven days each menstrual cycle ? (2) Does the pain interfere with daily activities? (3) Does the pain waken you at night? (4) Do you consider the pain severe enough to justify treatment? In 78 women clinical features of fibroadenosis were present, 9 had clear evidence of duct ectasia, and in the remaining 27 no definite abnormality was apparent on clinical examination or mammography but each required a large brassière cup size, and the cause of the pain may have been mechanical. A member of the nursing staff was trained by Memory World (UK) Limited to fit their brassière, which was chosen because it is designed on the cantilever principle and ensures that $75 \%$ of the weight of the breasts is distributed across the back and not on the shoulder straps. The side panels are shaped so that the brassière stays in place during any activity. It is provided in 144 different sizes to enable accurate fitting for any figure. Each patient was fitted and supplied with two brassières and followed up every three months for six to 18 months. The results were assessed and graded by two observers independently as follows: grade $1=$ complete relief of symptoms; grade 2 -improved but some residual pain or discomfort; grade $3=$ no improvement, or worse. The two observer agreed in all but six patients.

Ten patients who were lost to follow up and four who did not wear their brassière consistently were excluded from the results (table). Of the remaining 100 patients 26 obtained complete relief from pain, 49 were improved, 21 received no benefit from the brassière, and 4 became worse. Fifteen patients had received previous drug treatment for mastodynia, and of these 11 experienced improvement or relief of pain when they wore the brassière.

Clinical findings and response to treatment

\begin{tabular}{l|r|r|r|r}
\hline & \multirow{2}{*}{ Total } & \multicolumn{3}{|c}{ Grade of result } \\
\cline { 3 - 4 } & & 1 & 2 & 3 \\
\hline Patients with fibroadenosis & 68 & 15 & 38 & 15 \\
Patients with duct ectasia & 9 & 2 & 3 & 4 \\
Patients with mechanical pain & 23 & 9 & 8 & 6 \\
\hline
\end{tabular}

Of the 68 patients with clinical and radiological fibroadenosis 15 obtained complete relief, 38 were improved, and 15 were the same or worse. There was no correlation between the age of the patient or of the brassière cup size and the relief of symptoms.

\section{Discussion}

It is difficult to assess objectively a subjective symptom such as mammary pain. We have tried to reduce observer error by using standard questions and two observers to assess the replies, but a patient's attitude towards pain varies from day to day, which is a major weakness in this and similar trials. Relief of pain was not related significantly to age, clinical or radiological factors, or size of breasts. Advice about a supporting brassière should not be confined to women with large breasts. It was striking that many patients previously treated with drugs responded to the brassière, so it is desirable to try a supporting brassière before resorting to diuretics or hormones, which may have side effects. Our findings support the clinical impression that a fitted supporting brassière has considerable therapeutic value in many women with mastodynia.

We thank Mrs Upchurch of Memory World (UK) Limited for the supply of brassières, Mrs Ruth Mayes for fitting them, and Mrs Kay Newcomb for secretarial help.

${ }^{1}$ Velpeau, A, Maladies du Sein. Paris, Masson, 1854.

2 Atkins, H J B, British fournal of Surgery, 1950, 38, 147.

3 Bailey, H, and Love, M, Short Practice of Surgery, 13th edn. London, Lewis, 1965.

University Hospital of South Manchester, West Didsbury, Manchester M20 8LR

M C WILSON, MB, FRCS, tutor in surgery

R A SELLWOOD, CHM, FRCS, professor of surgery 